\title{
Mechanisms of Photoacclimation on Photosynthesis Level in Cyanobacteria
}

\author{
Sabina Jodłowska and Adam Latała \\ Department of Marine Ecosystems Functioning, Institute of Oceanography, \\ University of Gdansk, Gdynia \\ Poland
}

\section{Introduction}

Cyanobacteria are oxygenic photoautotrophic prokaryotes, which develop in many aquatic environments, both freshwater and marine. They successfully grow in response to increasing eutrophication of water, but also because of shifts in the equilibrium of ecosystems (Stal et al., 2003). Cyanobacteria possess many unique adaptations allowing optimal growth and persistence, and the ability to out-compete algae during favorable conditions. For instance, many species are buoyant due to the possession of gas vesicles, some of them are capable of fixing $\mathrm{N}_{2}$, and unlike algae, which require carbon dioxide gas for photosynthesis, most cyanobacteria can utilize other sources of carbon, like bicarbonate, which are more plentiful in alkaline or high $\mathrm{pH}$ environments. The cyanobacteria live in a dynamic environment and are exposed to diurnal fluctuations of light. Planktonic species experience differences in irradiance when mixed in the water column (Staal et al., 2002), whereas mat-forming cyanobacteria are exposed to changes in light intensity caused by sediment covering or sediment dispersion. Such rapidly changing environmental factors forced photoautotrophic organisms to develop many acclimation mechanisms to minimize stress due to low and high light intensities. High irradiance may damage photosynthetic apparatus by photooxidation of chlorophyll $a$ molecules. Some carotenoid pigments may provide effective protection against such disadvantageous influence of light (Hirschberg \& Chamovitz, 1994; Steiger et al., 1999; Lakatos et al., 2001; MacIntyre et al., 2002). Photosynthetic organisms respond to decreased light intensity by increasing the size or/and the number of photosynthetic units (PSU) whose changes, in turn, can be reflected in characteristic patterns of P-E curves (Platt et al., 1980; Prézelin, 1981; Ramus, 1981; Richardson et al., 1983; Henley, 1993; Dring, 1998; Mouget et al., 1999; MacIntyre et al., 2002; Jodłowska \& Latała, 2010). Variation in a and $\mathrm{P}_{\mathrm{m}}$ (expressed per biomass or per chlorophyll $a$ unit) plays a key part in interpreting physiological responses to changes in environmental conditions.

The aim of this review was to present exceptional properties of two different cyanobacteria, planktonic and benthic, their abilities to changing environmental condition, especially to irradiance. This information would be helpful in understanding the phenomenon of mass formation of cyanobacterial blooms worldwide, and would be very useful to interpret the domination of cyanobacteria in water ecosystem in summer months. 


\section{Light as a major factor controlling distribution, growth and functionality of photoautotrophic organisms}

Light is one of the main trophic and morphogenetic factors in the life of photosynthetic organisms. Intensity, quality and the time of light impact affect photosynthesis, which is responsible for producing organic matter, cell division and the growth rate of organism. The positive effect of increasing light intensity states only to a point, after which stabilization or even a drop in cell division takes place (Ostroff et al., 1980; Latała \& Misiewicz, 2000).

Effect of light on organisms can be investigated in two ways, firstly in ecological perspective i.e. paying special attention to the influence of this factor on distribution, and secondly in physiological point of view studying mechanisms of acclimation facilitating to survive in changing environmental conditions. Light is one of the main factors controlling the distribution of photoautotrophs in water column demonstrating their light preferences. Similarly to vascular plants, algae and cyanobacteria may also indicate their shadowtolerant features or heliophylous character (Falkowski \& La Roche, 1991). This phenomenon is observed both in case of benthic forms attached to the bottom and planktonic form floated in water column. Shadow-tolerant autotrophs concentrate in deeper water, where intensity of light is significantly lower, whereas heliophylous ones, preferring higher light intensity to growth and functionality, live in shallows. However, at surface layer of water phototrophic organisms are exposed to harmful effect of very high intensity of light and also effect of ultraviolet radiation, what may cause photoinhibition. Moreover, at deep water body we can define the level, below which photoautotrophic life gradually disappeared. The depth, at which anabolic and catabolic processes are balanced, is named as compensation level. Below this level light condition are insufficient, so that photosynthetic organisms are not able to normally develop and reproduce (Falkowski \& La Roche, 1991).

In natural conditions, phytoplankton which is vertically transferred within the euphotic zone experience not only changes of intensity but as well spectral quality (Rivkin, 1989). Spectral composition of downwelling light change progressively with increasing depth. Changes in spectral quality depend on the absorption spectra and scattering of the suspended particles within the water column and on absorption of water itself and the angle at which light impinges the water surface (Staal et al., 2002). In regions poor in nutrients the longer wavelengths are selectively absorbed within the upper ca $10 \mathrm{~m}$ and only blue-green light remains. However, in coastal regions rich in biogenic substances and yellow substances the shorter wavelengths are rapidly absorbed (Kirk, 1983; Rivkin, 1989).

When autotrophic organisms experience changes in light regime, both intensity and spectral quality, acclimation of photosynthetic apparatus to variable light condition is observed. Photoacclimation of these organisms is linked to alterations in total cellular concentration of light-harvesting and reaction centre pigments, and also in the ratio of different pigments. Generally, one observes an inverse correlation between light intensity and pigment content: the less light energy available, the more photosynthetic pigments are synthesized by the cells (Tandeau de Marsac \& Houmard, 1988). According to the idea proposed by Engelmann in 1883 different groups of marine algae dominate the benthic vegetation at different depths because their pigment composition adapts them for absorption, and hence photosynthesis, in light quality that prevails at that depth. This phenomenon is known as chromatic adaptation. It has often been pointed out that this concept is based on extremely superficial generalizations about the vertical distribution of benthic algae, since the representatives of most of the major groups can be observed at most depths (Dring, 1992). Laboratory studies 
of marine algae grown at different light intensities and different light spectrum suggest that phenotypic variations in pigment composition with depth are controlled by the irradiance level and not by the quality of the light (Ramus, 1981; Dring, 1992). However, the effect of light wavelength on pigment content of the cells appears to be restricted to some cyanobacteria. Changes in cell pigmentation in response to spectral quality of light result from modifications of the relative amounts of phycoerythrin (PE) and phycocyanin (PC). These phycobiliproteins are the major light-harvesting pigments used to drive photosynthesis. Only cyanobacteria which are able to synthesize PE can undergo complementary chromatic adaptation (Tandeau de Marsac \& Houmard, 1988).

Light quality may be important factor controlling and regulating metabolic processes in algae and cyanobacteria, however in this study we consider to discuss the effect of changes of light intensity on photoacclimation on photosynthesis level.

\section{Photosynthesis and light response curves}

The photosynthesis rate achieved by a photoautotroph cell depends on the rate of capture of quantum of light. Certainly, this is determined by the light absorption properties of the photosynthetic biomass, composition of photosynthetic pigments in the cell and by the intensity and spectral quality of the field (Kirk, 1996).

The relationship between photosynthesis rate and light intensity is well described by photosynthetic light response curves (P-E). P-Es are very useful tools to predict primary productivity, and their analysis provides a lot of valuable information about photoacclimation mechanisms of cells (Platt et al., 1980; Ramus, 1981; Richardson, 1983; Henley, 1993; Dring, 1998; MacIntyre et al., 2002). The changes in concentration of chlorophyll $a$ and other photosynthetic pigments in cell influence the course of P-E curves, which illustrate maximum rate of photosynthesis $\left(\mathrm{P}_{\mathrm{m}}\right)$, the initial slope of photosynthetic curves $(\alpha)$, the compensation $\left(\mathrm{P}_{c}\right)$ and saturation irradiances $\left(\mathrm{E}_{\mathrm{k}}\right.$; the intercept between the initial slope of $\mathrm{P}-\mathrm{E}$ and $\mathrm{P}_{\mathrm{m}}$ ) and dark respiration (R). The initial slope of photosynthetic curves at limiting light intensity $(\alpha)$ is a function of both light-harvesting efficiency and photosynthetic energy conversion efficiency (Henley, 1993). An increase of chlorophyll $a$ concentration in the cell of photoautotrophic organism improves the effective absorption of light, what causes an increase of the P-E slope, in case the rate of photosynthesis is expressed in biomass unit. However, if photosynthesis is expressed in chlorophyll unit, it will not be observed the variability of a parameter. It is because of the photosynthetic rate at the limiting light intensity is proportional to the concentration of chlorophyll $a$ (Dring, 1998). The chlorophyll $a$ is arranged in the thylakoid membranes in photosynthetic units (PSU), each of which consists of 300-400 chlorophyll molecules associated with a single reaction centre. An increase in pigment concentration could be achieved either by building extra molecules into the existing PSUs without changing the number of reaction centers (called as a change of PSU size) or by building up complete new PSUs without changing their size (called as a change of PSU number) (Dring, 1998). These two mechanisms of photoacclimation have quite different effects on values of $\mathrm{P}_{\mathrm{m}}$. Since $\mathrm{P}_{\mathrm{m}}$ is related to the number of reaction centers available, an increase in the size of PSUs have no effect on the maximum photosynthesis in biomass unit, that is why the photoautotrophs with different concentration of chlorophyll $a$ have different P-E slope, but the same value of $\mathrm{P}_{\mathrm{m}}$. If, however, the photosynthesis rate is expressed in chlorophyll $a$, the value of $\mathrm{P}_{\mathrm{m}}$ will drop with an increase of chlorophyll a concentration, but the P-E slope remains constant. 
However, when the number of PSUs increases proportionally to the increase in chlorophyll a concentration, the maximum photosynthesis in biomass unit will also increase in proportion to the chlorophyll $a$ concentration, but this means that $\mathrm{P}_{\mathrm{m}}$ in chlorophyll unit will be constant (Dring, 1998). According to the Ramus (1981) model, if the number of PSUs increases, more quantum of light is necessary to saturate the photosynthesis (higher $E_{k}$ and $\left.P_{m}\right)$, but if only the size of PSUs increases without any change of their number, not much light will be need to saturate the photosynthesis (lower $\mathrm{E}_{\mathrm{k}}$ and $\mathrm{P}_{\mathrm{m}}$ ). In the second case, PSU will be working more effectively (Lobban and Harrison, 1997).

\section{Photoacclimation strategies in two strains of cyanobacteria: Planktonic Nodularia spumigena and benthic Geitlerinema amphibium}

Cyanobacteria are very interesting material to study relationships between biological activity of organism and various environmental factors, because they often exist in extreme circumstances and can acclimate efficiently to changing environmental conditions (Latała \& Misiewicz, 2000).

The experiments were conducted on two different strains of Baltic cyanobacteria: planktonic Nodularia spumigena and benthic Geitlerinema amphibium. The investigated strains were isolated from southern Baltic Sea, exactly from the coastal zone of the Gulf of Gdańsk, and now they were maintained as an unialgal cultures in the Culture Collection of Baltic Algae (CCBA) (http://ccba.ug.edu.pl) at the Institute of Oceanography, University of Gdańsk, Poland (Latała et al., 2006). Buoyant cyanobacteria, like N. spumigena, previously mixed throughout the water column, float to the surface of water, where their cells are exposed to full sunlight, and this abrupt change in irradiance may induce photoinhibition (Ibelings, 1996). This species of cyanobacterium always occurs at water temperatures over $18^{\circ} \mathrm{C}$ and during weather conditions conductive to water column thermal stratification (Hobson et al., 1999). It is one of the filamentous cyanobacteria, which regularly occurs in the Baltic water in summer and often forms toxic blooms. N. spumigena grows especially well in the illuminated upper layer of the euphotic zone. In the Baltic Sea, it is most abundant to depths of $5 \mathrm{~m}$ (Hajdu et al., 2007), but it is also observed as deep as $18 \mathrm{~m}$ (Stal \& Walsby 2000; Jodłowska \& Latała, 2010). Similarly, mat-forming cyanobacterium, like G. amphibium, experience changes in light regime. These organisms may periodically be covered by a layer of sediment, which limits availability of light. On the other hands, sediment dispersion can lead to a rise in light intensity. G. amphibium, as a permanent element of summer microbial mats in the Gulf of Gdańsk (Southern Baltic) (Witkowski, 1986), may be an example of how organisms make use of their outstanding acclimation ability in the best possible way (Jodłowska \& Latała, 2010).

According to literature data cyanobacteria are generally recognized to prefer low light intensity for growth and photosynthesis (Fogg \& Thake, 1987; Ibelings, 1996). However, the investigated strain of $N$. spumigena was found to be well acclimated to relatively high light intensity $\left(290 \mu \mathrm{mol}\right.$ photons $\left.\cdot \mathrm{m}^{-2} \cdot \mathrm{s}^{-1}\right)$, which was especially evident within the range of temperature $15-20^{\circ} \mathrm{C}$ (Fig. 1A). The factorial experiments with $N$. spumigena showed that irradiance had a promoting effect on cyanobacterial concentration, but the interaction between increasing irradiance of over about $100 \mu \mathrm{mol}$ photons $\cdot \mathrm{m}^{-2} \cdot \mathrm{s}^{-1}$ and increasing temperature over about $23^{\circ} \mathrm{C}$ inhibited the filament concentration. Prolonged exposure to high light intensity may cause photoinhibition, and induce harmful effects resulting from 
increased temperatures. Optimal growth conditions were noted at about 180-290 $\mu \mathrm{mol}$ photons $\cdot \mathrm{m}^{-2} \cdot \mathrm{s}^{-1}$ and $15-17^{\circ} \mathrm{C}$. The maximum number of filament units (about $5 \cdot 10^{5}$ filament units $\mathrm{ml}^{-1}$ ) was about $10 \mathrm{x}$ greater than the minimum one. Similarly, the factorial experiments on G. amphibium showed that both irradiance and temperature have promoting effect on cyanobacterial culture concentration, but this positive effect was observed up to $120 \mu \mathrm{mol}$ photons $\mathrm{m}^{-2} \cdot \mathrm{s}^{-1}$ at $35^{\circ} \mathrm{C}$ as well as up to $170 \mu \mathrm{mol}$ photons $\mathrm{m}^{-2} \mathrm{~s}^{-1}$ at $30^{\circ} \mathrm{C}$ (Fig. 1B). However, the interaction between temperature of $35^{\circ} \mathrm{C}$ and light intensity of $170 \mu \mathrm{mol}$ photons $\mathrm{m}^{-2} \cdot \mathrm{s}^{-1}$ resulted in growth inhibition (Latała \& Misiewicz, 2000). An excess of light energy absorbed by photosynthetic pigments together with high-temperature stress may accelerate photoinhibition by inhibiting the repair of photodamaged PSII (Allakhverdiev et al., 2008; Takahashi \& Murata, 2008; Takahashi \& Badger, 2011). Richardson \& her co-workers (1983)
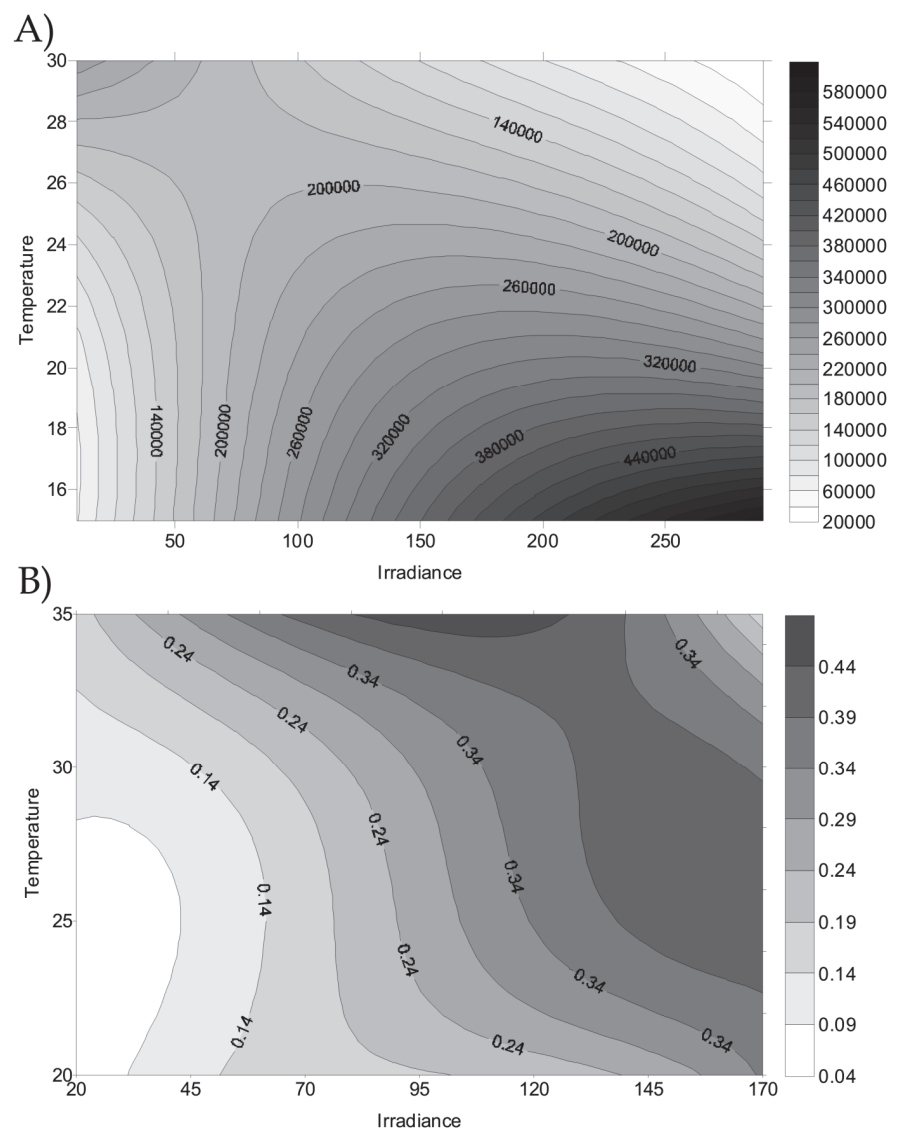

Fig. 1. Response-surface estimation at different temperatures $\left({ }^{\circ} \mathrm{C}\right)$ and irradiances $(\mu \mathrm{mol}$ photons $\cdot \mathrm{m}^{-2} \cdot \mathrm{s}^{-1}$ ) of: A) N. spumigena filament concentration (1 filament unit $\left.=100 \mu \mathrm{m}\right)$, B) $\mathrm{G}$. amphibium optical density at $750 \mathrm{~nm}$. Experimental cultures were grown in three replicates and the measurements of culture were done on the last day of incubation in the exponential growth phase. 
suggested that photoinhibition of the growth and photosynthesis occurred in the natural populations at above $200 \mu \mathrm{mol}$ photons $\cdot \mathrm{m}^{-2} \cdot \mathrm{s}^{-1}$, although a lot of species can be subjected to this phenomenon at lower irradiance. Aphanizomenon ovalisporum indicated inhibition of the cell concentration even at $50 \mu \mathrm{mol}$ photons $\cdot \mathrm{m}^{-2} \cdot \mathrm{s}^{-1}$ and $20-35^{\circ} \mathrm{C}$ (Hadas et al., 2002).

The experiments on $N$. spumigena and G. amphibium showed that both irradiance and temperature were important factors contributing to the variation of chlorophyll $a$ content at the investigated strains, but the influence of irradiance was higher (Latała \& Misiewicz, 2000; Jodłowska \& Latała, 2010) (Fig. 2). In two investigated strains, pigment content was negatively affected by irradiance and positively by temperature. The highest values of pigment content at low light treatment and high temperature treatment were almost 95\% and $85 \%$ for N. spumigena and G. amphibium, respectively, higher than the lowest ones at high light treatment and low temperature treatment.
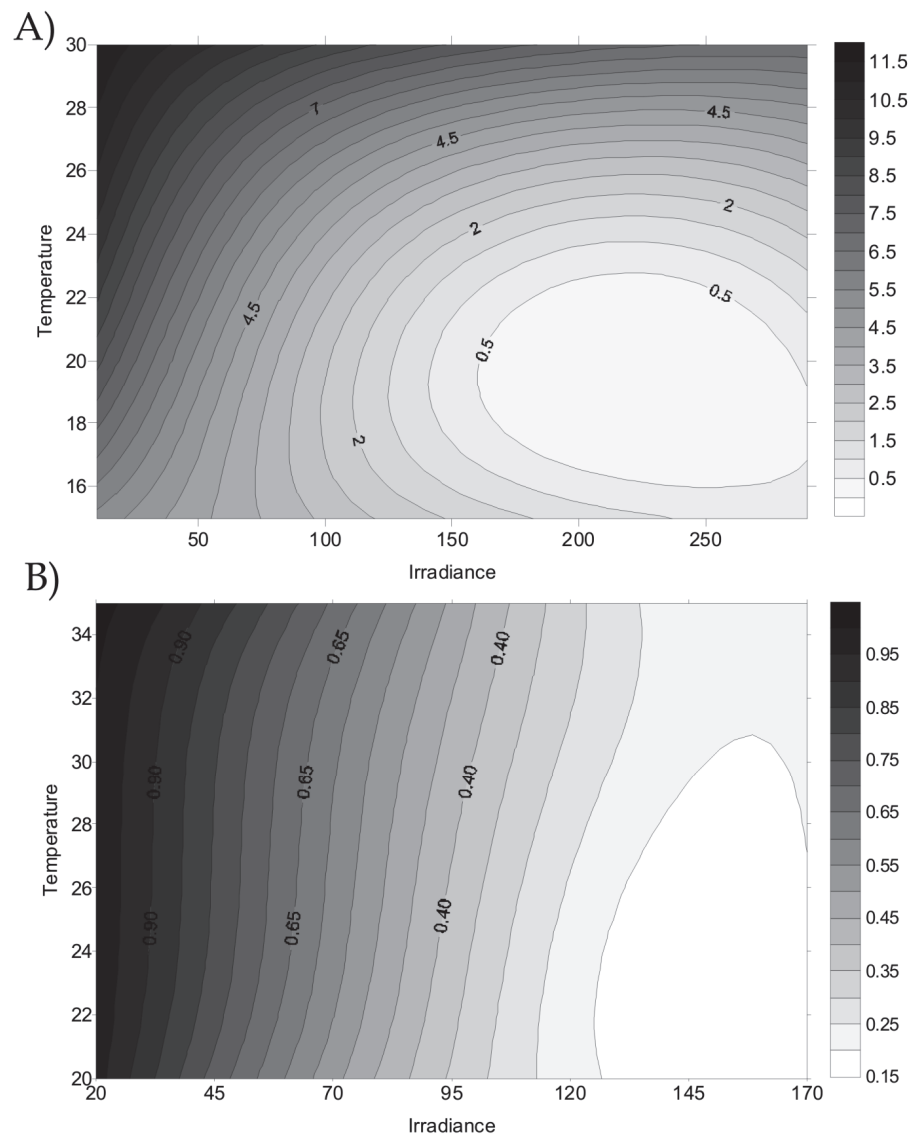

Fig. 2. Response-surface estimation of chlorophyll $a$ content (pg filament unit ${ }^{-1}$ ): A) $N$. spumigena and B) G. amphibium at different temperatures $\left({ }^{\circ} \mathrm{C}\right)$ and irradiances ( $\mu$ mol photons $\cdot \mathrm{m}^{-2} \cdot \mathrm{s}^{-1}$ ). 
The lower cellular content of chlorophyll $a$ noted in the population acclimated to high light is associated with a decrease in the size and/or the number of photosynthetic units (PSUs) that can be reflected by P-E curves (Platt et al., 1980; Prézelin, 1981; Ramus, 1981; Richardson et al., 1983; Henley, 1993; Dring, 1998; Mouget et al., 1999; MacIntyre et al., 2002; Jodłowska \& Latała, 2010). P-E curves obtained for N. spumigena and G. amphibium grown under different light and temperature conditions illustrate that these two strains conforms to more than one of the photoadaptive models used to categorize species (Fig. 3) (Jodłowska \& Latała, 2010). Photosynthetic rates, normalized to biomass and chlorophyll unit, were plotted against irradiance. The P-E curves were fitted to the data with Statistica using the mathematical function by Platt \& Jassby (1976), as follows: $P=P_{m} \cdot \tanh \left(\alpha \cdot E / P_{m}\right)+R_{d}$. To illustrate the course of P-E curves, the results recorded at $15^{\circ} \mathrm{C}$ were chosen (Fig. 3 and 4 ). In N. spumigena culturing at $15^{\circ} \mathrm{C}$, the biomass-specific $\mathrm{P}_{\mathrm{m}}$ was about $70 \%$ higher in the low light treatment than in the high light treatment (Fig. 3A), whereas in G. amphibium the same difference was about $60 \%$ (Fig. 3B). Since the biomass-specific $\mathrm{P}_{\mathrm{m}}$ noted in the strains acclimated to low light was higher than that grown in high light, it indicates a change in the number of the PSUs. However, higher chla-specific $\mathrm{P}_{\mathrm{m}}$ in the strains acclimated to high light in comparison to that in the low light strain indicates there was a change in the size of the PSUs. In N. spumigena culturing at $15^{\circ} \mathrm{C}$, the chlorophyll-specific $\mathrm{P}_{\mathrm{m}}$ was about $45 \%$ higher in the high light treatment than in the low light treatment (Fig. 3B), whereas in G. amphibium the same difference was about $70 \%$ (Fig. 4B).

These two mechanisms of photoacclimation, concerning the changes in the size and the number of PSUs, explain significant changes in photosynthesis rate and its parameters upon the influence of different light intensities and temperatures (Fig. 5). It is noteworthy that $N$. spumigena and $G$. amphibium exhibit substantial changes in $E_{k}$ and $P_{c}$ within the range of irradiance tested. However, it is typical for $\mathrm{E}_{\mathrm{k}}$ values to increase in phototrophic populations as irradiance increases (Richardson et al., 1983), whereas the link between the evolution of compensation light intensity $\left(\mathrm{P}_{\mathrm{c}}\right)$ and increased irradiance is somewhat more characteristic of Chlorophyta (Falkowski \& Owens, 1980). The results of variance analysis showed that both irradiance and temperature were important factors contributing to the variation of $E_{k}$ and $P_{c}$ parameters at the investigated strains, but the influence of irradiance was higher. In $N$. spumigena, the minimum values of $\mathrm{E}_{\mathrm{k}}$ (about $145 \mu \mathrm{mol}$ photons $\cdot \mathrm{m}^{-2} \cdot \mathrm{s}^{-1}$ ) were about $47 \%$ lower than the maximum ones (about $275 \mu \mathrm{mol}$ photons $\cdot \mathrm{m}^{-2} \cdot \mathrm{s}^{-1}$ ) (Fig. 5A), but in G. amphibium the differences were higher, and were about $94 \%$ (Fig. 5B). In contrast, in cyanobacterium $N$. spumigena, the minimum values of $\mathrm{P}_{\mathrm{c}}$ (about $10 \mu \mathrm{mol}$ photons $\cdot \mathrm{m}^{-2} \cdot \mathrm{s}^{-1}$ ) were lower about $95 \%$ than the maximum ones (about $180 \mu \mathrm{mol}$ photons $\cdot \mathrm{m}^{-2} \cdot \mathrm{s}^{-1}$ ) (Fig. $5 \mathrm{C}$ ), whereas in G. amphibium the minimum $\mathrm{P}_{\mathrm{c}}$ (about $5 \mu \mathrm{mol}$ photons $\cdot \mathrm{m}^{-2} \cdot \mathrm{s}^{-1}$ ) were lower about 93\% than the maximum ones (about $70 \mu \mathrm{mol}$ photons $\cdot \mathrm{m}^{-2} \cdot \mathrm{s}^{-1}$ ) (Fig. 5D). The obtained minimum values of $E_{k}$ and $P_{c}$ are close to those reported for shadow-tolerant plants, while the maximum ones are close to those noted in heliophylous plants (Rabinowitch, 1951; Wallentinus, 1978). Achieved results for both parameters showed good acclimation capacity of the investigated species to irradiance changes. It is also noteworthy that P-E curves for investigated cyanobacteria did not indicate photosynthetic photoinhibition until approximately 700-1000 $\mu \mathrm{mol}$ photons $\mathrm{m}^{-2} \mathrm{~s}^{-1}$, even if the cyanobacteria were acclimated to very low light intensity (5 $-10 \mu \mathrm{mol}$ photons $\mathrm{m}^{-2} \mathrm{~s}^{-1}$ ). Moisander et al. (2002) did not also note this phenomenon in N. spumigena at irradiances exceeding $1000 \mu \mathrm{mol}$ photons $\mathrm{m}^{-2} \mathrm{~s}^{-1}$. 

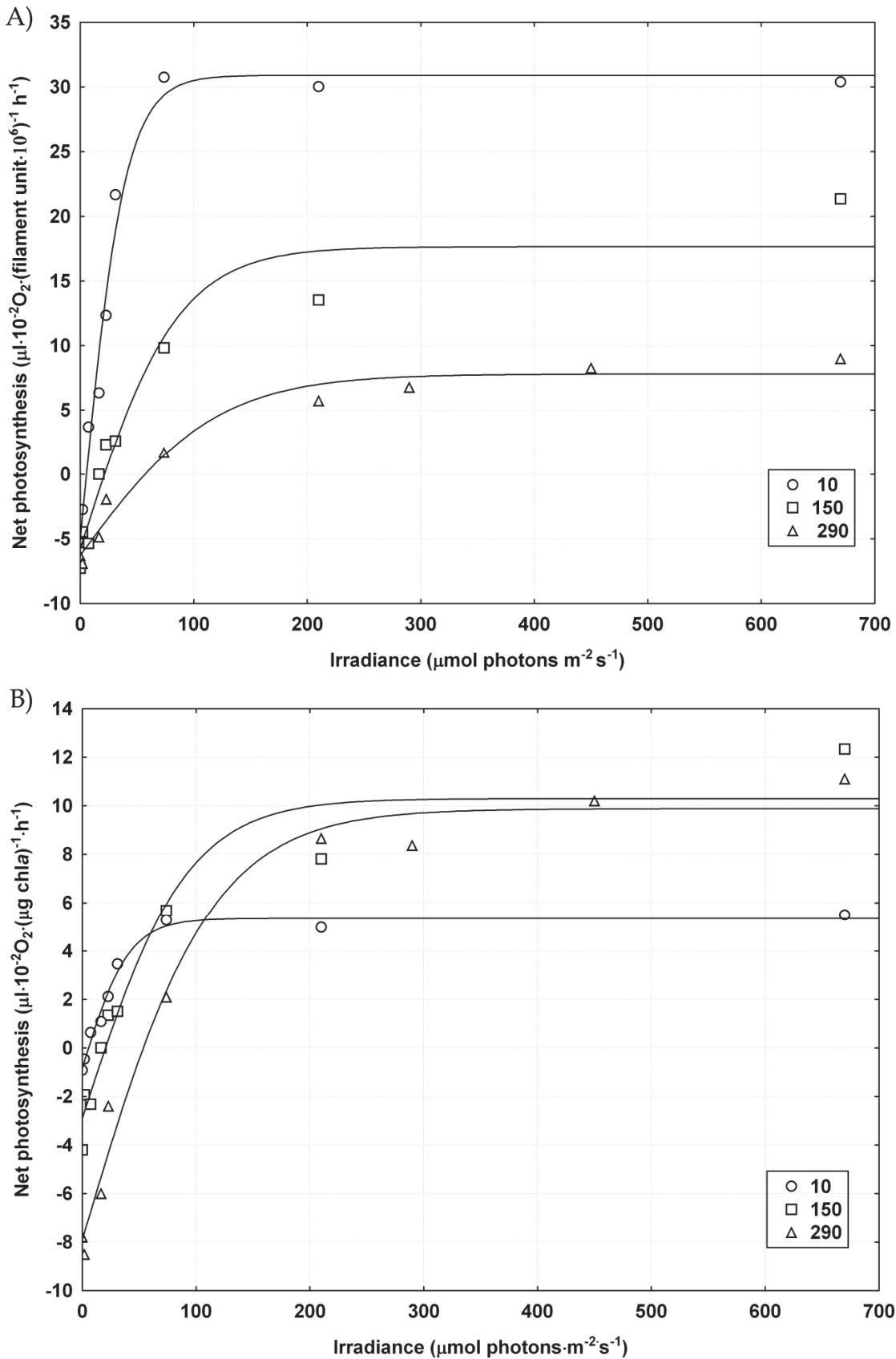

Fig. 3. P-E curves for $N$. spumigena growing at three light intensity ( $\mu \mathrm{mol}$ photons $\cdot \mathrm{m}^{-2} \cdot \mathrm{s}^{-1}$ ) and at $15^{\circ} \mathrm{C}$ : A) in filament unit, B) in chlorophyll unit (Jodłowska \& Latała, 2010). 


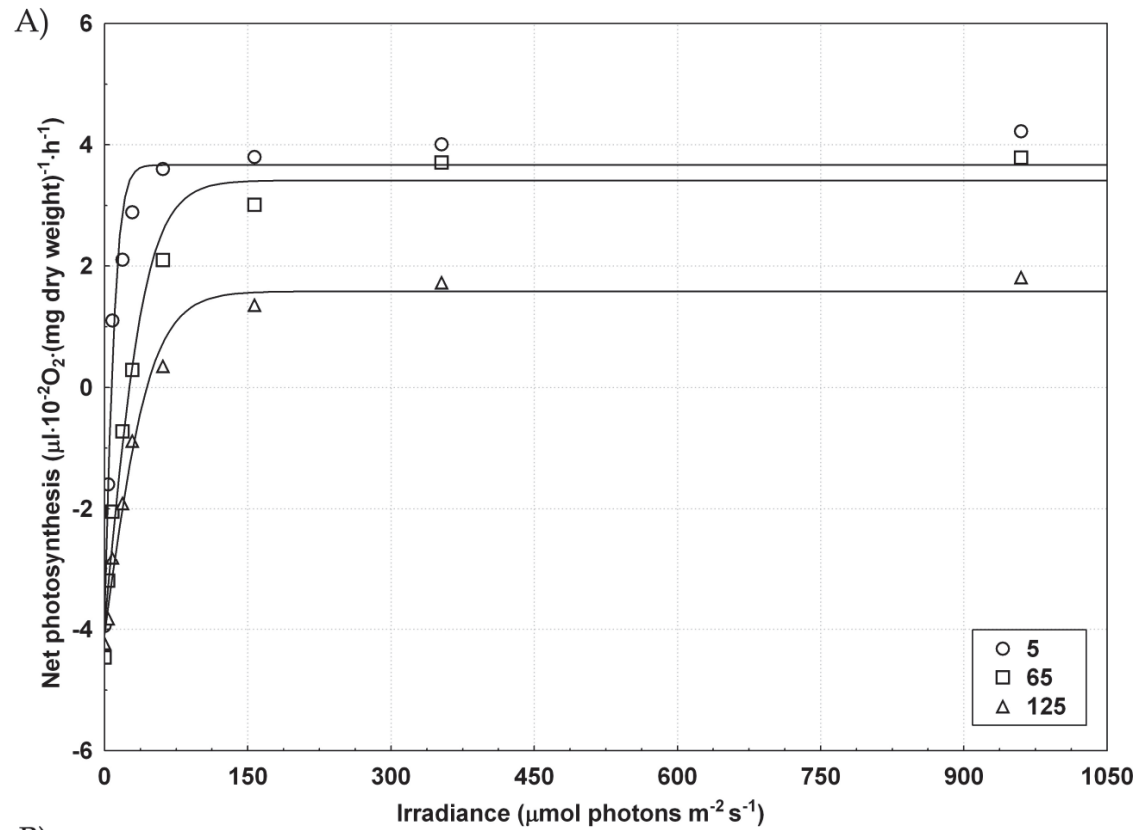

B)

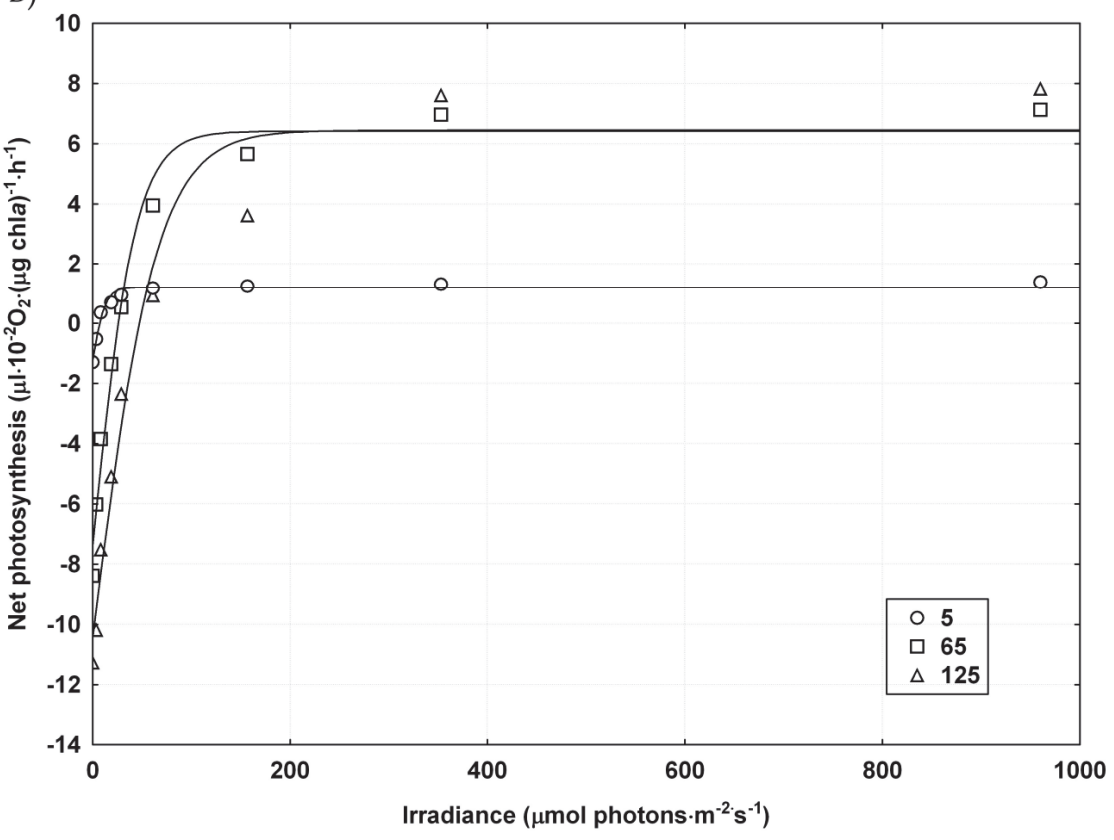

Fig. 4. P-E curves for G. amphibium growing at three light intensity ( $\mu \mathrm{mol}$ photons $\left.\cdot \mathrm{m}^{-2} \cdot \mathrm{s}^{-1}\right)$ and at $15^{\circ} \mathrm{C}$ : A) in biomass unit, B) in chlorophyll unit. 
A)

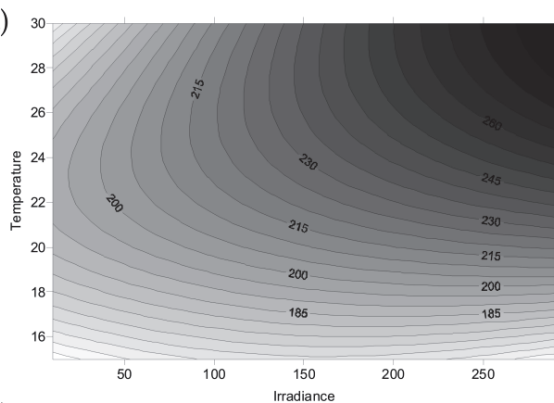

C)

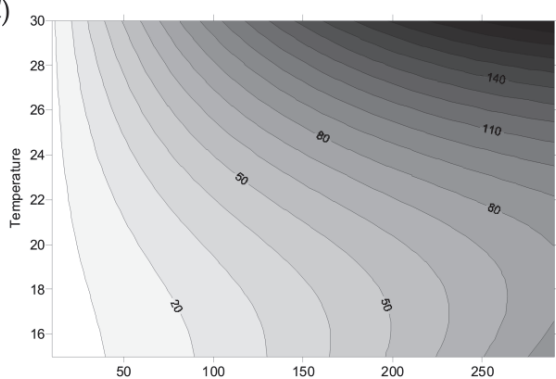

B)

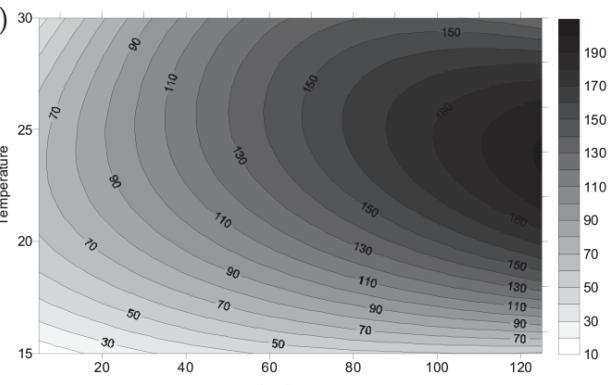

D)

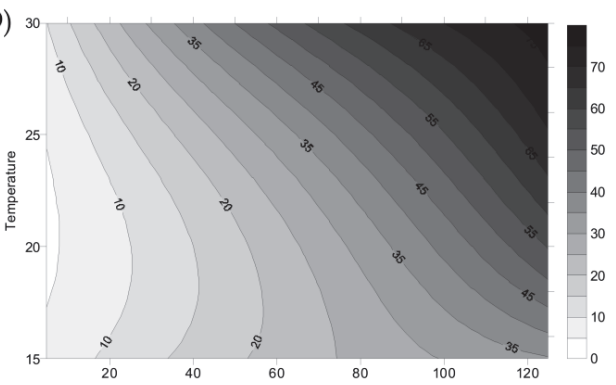

Fig. 5. Response-surface estimation at different temperatures $\left({ }^{\circ} \mathrm{C}\right)$ and irradiances $(\mu \mathrm{mol}$ photons $\left.\cdot \mathrm{m}^{-2} \cdot \mathrm{s}^{-1}\right)$ of $\mathrm{E}_{\mathrm{k}}\left(\mu \mathrm{mol}\right.$ photons $\left.\mathrm{m}^{-2} \mathrm{~s}^{-1}\right)$ for: A) N. spumigena, B) G. amphibium and $\mathrm{P}_{\mathrm{c}}$ ( $\mu \mathrm{mol}$ photons $\mathrm{m}^{-2} \mathrm{~s}^{-1}$ ) for: C) N. spumigena, D) G. amphibium.

\section{Conclusions}

Every phototrophic organisms, including cyanobacteria, differ in their light intensity range within which they grow and photosynthesize. This is determined by their optimal ecological requirements for light and controlled by metabolic properties of each species (Collier et al., 1978; Richardson et al., 1983). The P-E response curves, derived from short-term measurement, provides an information about condition of photosynthetic apparatus and yields insight into the regulation of energy and material balance of the cell (MacIntyre et al., 2002).

In this review, we give importance of interpreting P-Es in the context photoacclimation mechanisms in cyanobacteria. The current experiments on two different strains of cyanobacteria demonstrated their capacity to acclimate to irradiance, which is reflected in the wide range of changes in the growth, pigment composition as well as photosynthetic activity of the examined cyanobacteria. The studied parameters demonstrated their exceptional adaptability of changes, which explain why these strains grow successfully in well-illuminated habitats and also can grow well in position with limited access of light.

The identification of factors that regulate the growth and photosynthetic activity of cyanobacteria can be helpful for understanding the ecological triggers of cyanobacterial blooms.

\section{Reference}

Allakhverdiev, S.I.; Kreslavski, V.D.; Klimov, V.V.; Los, D.A.; Carpentier, R. \& Mohanty, P. (2008). Heat stress: an overview of molecular responses in photosynthesis. Photosynthesis Research 98: 541-550. 
Dring, M.J. (1998). The biology of marine plants. Cambridge University Press, Cambridge. 199 pp. Falkowski, P.G. \& Owens, T.G. (1980). Light-shade adaptation: two strategies in marine phytoplankton. Plant Physiology 66: 592-595.

Falkowski, P.G.; LaRoche, J. (1991). Acclimation to spectral irradiance in algae. Journal of Phycology 27: 8-14.

Fogg, G.E. \& Thake, B. (1987). Algal cultures and phytoplankton ecology. University of Wisconsin Press, Madison and Milwaukee. 269 pp.

Hadas, O.; Pinkas, R.; Malinsky-Rushansky, N.; Shalev-Alon, G.; Delphine, E.; Berner, T.; Sukenik, A. \& Kaplan, A. (2002). Physiological variables determined under laboratory conditions may explain the bloom of Aphanizomenon ovalisporum in Lake Kinneret. European Journal of Phycology 37: 259-267.

Hajdu, S.; Höglander, H. \& Larsson, U. (2007). Phytoplankton vertical distribution and composition in Baltic Sea cyanobacterial blooms. Harmful Algae 6: 189-205.

Henley, W.J. (1993). Measurement and interpretation of photosynthetic light-response curves in algae in the context of photoinhibition and diel changes. Journal of Phycology 29: 729-739.

Hirschberg, J. \& Chamovitz, D. (1994). Carotenoids in cyanobacteria. In: Bryant DA (ed) The molecular biology of cyanobacteria, Kluwer Academic Publishers, Netherlands, pp 559579.

Hobson, P.; Burch, M. \& Fallowfield, H.J. (1999). Effect of total dissolved solids and irradiance on growth and toxin production by Nodularia spumigena. Journal of Applied Phycology 11: 551-558.

Ibelings, B.W. (1996). Changes in photosynthesis in response to combined irradiance and temperature stress in cyanobacterial surface waterblooms. Journal of Phycology 32: 549-557.

Jodłowska, S. \& Latała, A. (2010). Photoacclimation strategies in the toxic cyanobacterium Nodularia spumigena (Nostocales, Cyanobacteria). Phycologia 49: 203-211.

Krik, J.T.O. (1994). Light and photosynthesis in aquatic ecosystems. Cambridge University Press, Cambridge. 509 pp.

Lakatos, M.; Bilger, W.; Büdel, B. (2001). Carotenoid composition of terrestrial Cyanobacteria: response to natural light conditions in open rock habitats in Venezuela. European Journal of Phycology 36: 367-375.

Latała, A.; Misiewicz, S. (2000). Effects of light, temperature and salinity on the growth and chlorophyll-a content of Baltic cyanobacterium Phormidium sp. Archiv für Hydrobiologie 136; Algological Studies 100: 157-180.

Latała, A.; Jodłowska, S. \& Pniewski, F. (2006). Culture Collection of Baltic Algae (CCBA) and characteristic of some strains by factorial experiment approach. Archiv für Hydrobiologie 165, Algological Studies 122: 137-154.

Lobban, C. S. \& Harrison, P. J. (1997). Seaweed Ecology and Physiology. Cambridge University Press, Cambridge, UK, 366 pp.

MacIntyre, H.L.; Kana, T.M.; Anning, T. \& Geider, R.J. (2002). Photoacclimation of photosynthesis irradiance response curves and photosynthetic pigments in microalgae and cyanobacteria. Journal of Phycology 38: 17-38.

Moisander, P.H.; McClinton III, E. \& Paerl, H.W. (2002). Salinity effects on growth, photosynthetic parameters, and nitrogenase activity in estuarine planktonic cyanobacteria. Microbial Ecology 43: 432-442.

Mouget, J.-L.; Tremblin, G.; Morant-Manceau, A.; Morancais, M. \& Robert, J.-M. (1999). Long-term photoacclimation of Haslea ostrearia (Bacillariophyta): effect of irradiance 
on growth rates, pigment content and photosynthesis. European Journal of Phycology 34: 109-115.

Ostroff, C.R.; Karlander, E.P. \& Van Valkenburg, S.D. (1980). Growth rates of Pseudopedinella pyriforme (Chrysophyceae) in response to 75 combination of light, temperature and salinity. Journal of Phycology 16: 421-423.

Platt, T. \& Jassby, A.D. (1976). The relationship between photosynthesis and light for natural assemblages of coastal marine phytoplankton. Journal of Phycology 12: 421-430.

Platt, T.; Gallegos, C.L. \& Harrison, W.G. (1980). Photoinhibition of photosynthesis in natural assemblages of marine phytoplankton. Journal of Marine Research 38: 687701.

Prézelin, B.B. (1981). Light reactions in photosynthesis. In: Platt T (ed) Physiological bases of phytoplankton ecology, Canadian Bulletin of Fisheries and Aquatic Sciences, no. 210, Ottawa, 1-43 pp.

Rabinowitch, E.I. (1951). Photosynthesis and Related Processes. Vol. II, part 1. Interscience Publishers, New York. 1208 pp.

Ramus, J. (1981). The capture and transduction of light energy. In: The biology of seaweeds (Ed. by C.S. Lobban \& M.J. Wynne), Blackwell Scientific, Oxford. 458-492 pp.

Richardson, K.; Beardall, J. \& Raven, J.A. (1983). Adaptation of unicellular algae to irradiance: an analysis of strategies. New Phytologist 93: 157-191.

Rivkin, R.B. (1989). Influence of irradiance and spectral quality on the carbon metabolism of phytoplankton. I. Photosynthesis, chemical composition and growth. Marine Ecology Progress Series Vol. 55 (1989), pp. 291-304.

Staal, M.; te Lintel Hekkert, S.; Herman, P. \& Stal, L.J. (2002). Comparison of model describing light dependence of $\mathrm{N}_{2}$ fixation in heterocystous cyanobacteria. Applied and Environmental Microbiology 68(9): 4679-4683.

Stal, L.J. \& Walsby, A.E. (2000). Photosynthesis and nitrogen fixation in a cyanobacterial bloom in the Baltic Sea. European Journal of Phycology 35: 97-108.

Stal, L.J.; Albertano, P.; Bergman, B.; Bröckel, K.; Gallon, J.R.; Hayes, P.K.; Sivonen, K. \& Walsby, A.E. (2003). BASIC: Baltic Sea cyanobacteria. An investigation of the structure and dynamic of water blooms of cyanobacteria in the Baltic Sea response to a changing environment. Continental Shelf Research 23: 1695-1714.

Steiger, S.; Schäfer, L. \& Sandmann, G. (1999). High-light-dependent upregulation of carotenoids and their antioxidative properties in the cyanobacterium Synechocystis PCC 6803. Journal of Photochemistry and Photobiology 52: 14-18.

Takahashi, S. \& Badger, M.R. (2011). Photoprotection in plants: a new light on photosystem II damage. Trends in Plant Science 16(1): 53-60. Plant Science 13(4): 178-182. Tandeau de Marsac, N. \& Houmard, J. (1988). Complementary chromatic adaptation: physiological conditions and action spectra. In: Methods in Enzymology (Ed. by L. Packer \& A.N. Glazer), Academic Press, New York. 318-328 pp.

Wallentinus, I. (1978). Productively studies on Baltic macroalgae. Botanica Marina 21: 365380.

Witkowski, A. (1986). Microbial mat with an incomplete vertical structure, from brackishwater environment, the Puck Bay, Poland, a possible analog of an "advanced anaerobic ecosystem"?. Origins of Life and Evolution of Biospheres 16(3-4): 337-338. 


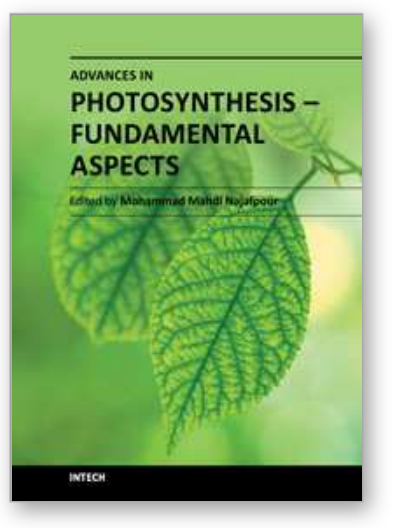

\section{Advances in Photosynthesis - Fundamental Aspects \\ Edited by Dr Mohammad Najafpour}

ISBN 978-953-307-928-8

Hard cover, 588 pages

Publisher InTech

Published online 15, February, 2012

Published in print edition February, 2012

Photosynthesis is one of the most important reactions on Earth. It is a scientific field that is the topic of many research groups. This book is aimed at providing the fundamental aspects of photosynthesis, and the results collected from different research groups. There are three sections in this book: light and photosynthesis, the path of carbon in photosynthesis, and special topics in photosynthesis. In each section important topics in the subject are discussed and (or) reviewed by experts in each book chapter.

\section{How to reference}

In order to correctly reference this scholarly work, feel free to copy and paste the following:

Sabina Jodłowska and Adam Latała (2012). Mechanisms of Photoacclimation on Photosynthesis Level in Cyanobacteria, Advances in Photosynthesis - Fundamental Aspects, Dr Mohammad Najafpour (Ed.), ISBN: 978-953-307-928-8, InTech, Available from: http://www.intechopen.com/books/advances-in-photosynthesisfundamental-aspects/mechanisms-of-photoacclimation-on-photosynthesis-level-in-cyanobacteria

\section{INTECH}

open science | open minds

\section{InTech Europe}

University Campus STeP Ri

Slavka Krautzeka 83/A

51000 Rijeka, Croatia

Phone: +385 (51) 770447

Fax: +385 (51) 686166

www.intechopen.com

\section{InTech China}

Unit 405, Office Block, Hotel Equatorial Shanghai

No.65, Yan An Road (West), Shanghai, 200040, China

中国上海市延安西路65号上海国际贵都大饭店办公楼 405 单元

Phone: +86-21-62489820

Fax: +86-21-62489821 
(C) 2012 The Author(s). Licensee IntechOpen. This is an open access article distributed under the terms of the Creative Commons Attribution 3.0 License, which permits unrestricted use, distribution, and reproduction in any medium, provided the original work is properly cited. 